\title{
Growth Deficiency of a Xanthomonas oryzae pv. oryzae fur Mutant in Rice Leaves Is Rescued by Ascorbic Acid Supplementation
}

\author{
Sujatha Subramoni and Ramesh V. Sonti \\ Centre for Cellular and Molecular Biology, Uppal Road, Hyderabad-500 007, India
}

Submitted 29 July 2004. Accepted 11 February 2005.

\begin{abstract}
Xanthomonas oryzae pv. oryzae causes bacterial leaf blight, a serious disease of rice. A mutation was isolated in the ferric uptake regulator (fur) gene of $X$. oryzae pv. oryzae and it was shown to result in the production of siderophores in a constitutive manner. The fur mutant is hypersensitive to the metallo-antibiotic streptonigrin, a phenotype that is indicative of intracellular free-iron overload, and also exhibits a slow growth phenotype on rich medium. The fur mutant is virulence deficient, hypersensitive to hydrogen peroxide, and exhibits reduced catalase activity. Exogenous supplementation with ascorbic acid (an antioxidant) rescues the growth deficiency of the fur mutant in rice leaves. The virulence deficiency of the $X$. oryzae pv. oryzae fur mutant is proposed to be due, at least in part, to an impaired ability to cope with the oxidative stress conditions that are encountered during infection.
\end{abstract}

Xanthomonas oryzae pv. oryzae causes bacterial leaf blight, a serious disease of rice. Some of the genes required for $X$. oryzae pv. oryzae virulence that have been previously described include gumG and gumM, involved in extracellular polysaccharide (EPS) biosynthesis (Dharmapuri and Sonti 1999; Rajeshwari and Sonti 2000); rpfC, involved in regulation of EPS biosynthesis (Tang et al. 1996); hrp and $a v r$, encoding components of a type III protein secretion system and its effectors and regulators (Bai et al. 2000; Kamdar et al. 1993; Yang et al. 2000; Zhu et al. 2000); xadA, encoding an adhesin-like protein (Ray et al. 2002); and phyA, which promotes utilization of phytic acid as a sole phosphate source (Chatterjee et al. 2003).

One of the critical factors for survival of many pathogens within their hosts is the availability of iron. In vertebrate hosts, iron sequestration upon infection is well known (Payne 1993; Weinberg 1984). In plants, several studies indicate that iron availability is likely to be a limiting factor for bacterial growth within the host (Mila et al. 1996; Neema et al. 1993). Previous work has indicated that $X$. oryzae pv. oryzae rpfF mutants are deficient for virulence and growth under low iron conditions (Chatterjee and Sonti 2002). Exogenous iron supplementation

Corresponding author: R. V. Sonti; Telephone: +91-40-27192577; Fax: +91-40-27160591; E-mail: sonti@ccmb.res.in and rvsonti@yahoo.com

Nucleotide and amino acid sequence data are available in the GenBank database under accession number AY688951. has been shown to promote in planta growth of the $X$. oryzae pv. oryzae rpfF mutants. These data suggest that the $r p f F$ gene promotes virulence of $X$. oryzae pv. oryzae by facilitating iron uptake.

Under aerobic conditions, iron is present in the form of insoluble ferric salts. Many bacteria secrete low molecular weight iron chelators called siderophores, which sequester $\mathrm{Fe}^{3+}$ with high affinity (Ratledge and Dover 2000). The siderophore- $\mathrm{Fe}^{3+}$ complex is taken up into the bacterial cell by active transport across the outer membrane, and the energy required for this process is transduced by the TonB complex (TonB, ExbB, and ExbD) of proteins (Postle and Kadner 2003). In X. campestris pv. campestris, a tonB mutant has been reported to be impaired for $\mathrm{Fe}^{3+}$ uptake and exhibit increased extracellular siderophore, indicating that TonB plays an important role in $\mathrm{Fe}^{3+}$ uptake by this bacterium (Wiggerich et al. 1997). Other methods of iron uptake from heme or host ironbinding proteins and direct $\mathrm{Fe}^{2+}$ transport also may be employed by pathogenic bacteria (Ratledge and Dover 2000; Velayudhan et al. 2000). However, excess iron in the cell can be toxic due to the ability of $\mathrm{Fe}^{2+}$ to catalyze the Fenton reaction, which generates cell-damaging hydroxyl radicals (Touati 2000). Hence, the expression of iron uptake functions must be tightly controlled, and this function is performed in many bacteria by the ferric-uptake regulator (Fur) protein.

Fur functions as a transcriptional repressor of iron uptake functions and iron-regulated genes in bacteria. The repressor binds as a dimer, with $\mathrm{Fe}^{2+}$ as corepressor, to specific sequences called Fur boxes that are located in the promoter regions of such genes (Ratledge and Dover 2000). Under conditions of iron starvation, the Fur protein is inactive and the Fur-regulated genes are transcribed. In addition to controlling genes involved in iron metabolism, Fur has been shown to regulate functions involved in varied cellular processes such as defense against acid shock and oxidative stress (Bijlsma et al. 2002; Thompson et al. 2002; Vasil and Ochsner 1999), enzymes involved in energy metabolism (Thompson et al. 2002; Vasil and Ochsner 1999), and production of virulence-associated functions in animal pathogens (Barton et al. 1996; Grifantini et al. 2003). Fur also appears to positively affect expression of certain genes for bacterioferritin, superoxide dismutase, and catalase. (Hassett et al. 1996; Vasil and Ochsner 1999). The effect might be through an indirect repressive mechanism because Fur represses the expression of small regulatory RNA molecules, which, in turn, inhibit the expression of target genes (Masse and Gottesman 2002; Wilderman et al. 2004). 
Interestingly, a mutation in the fur gene of Rhizobium leguminosarum has been shown to have no effect on the expression of several operons that are involved in iron acquisition (Wexler et al. 2003). Instead, another protein called RirA has been found to regulate genes involved in iron uptake (Todd et al. 2002). Among plant pathogens, reduced virulence has been associated with mutations in the fur gene of Erwinia chrysanthemi, which causes soft rot of African violets (Franza et al. 1999). In X. campestris pv. phaseoli, the Fur protein has been characterized with respect to primary structure and iron-dependent expression pattern (Loprasert et al. 1999) and shown to be capable of repressing a Fur-regulated promoter in Escherichia coli. The nucleotide sequences of fur genes from four xanthomonads have been determined (accession numbers AF146020, AF146021, AF146022, and AF146830). However, the role that the Fur protein plays in virulence of any member of the xanthomonad group of plant pathogens is unknown. In this article, the characteristics of a fur mutant of $X$. oryzae $\mathrm{pv}$. oryzae are reported.

\section{RESULTS}

Gene organization in the fur region of $X$. oryzae pv. oryzae.

A partial sequence (408 bp) of the $X$. oryzae pv. oryzae fur gene (available as accession no. AF146830) was used to obtain, through inverse polymerase chain reaction (PCR), the sequence of a $1.25-\mathrm{kb}$ genomic region containing the entire $X$. oryzae pv. oryzae fur gene $(411 \mathrm{bp})$ and flanking sequences. The sequenced region contained one complete open reading frame (ORF1) and two partial ORFs (ORF2 and ORF3) (Fig. 1). ORF1 (fur) is $411 \mathrm{bp}$ long and potentially encodes a protein of 136 amino acids. A BLAST search (Altschul et al. 1990) with the deduced amino acid sequence of fur revealed that it exhibits high similarity to the Fur proteins of $X$. campestris pv. phaseoli (AAD44804, 98\% similarity, 97\% identity), X. campestris pv. campestris (NP636842, 99\% similarity, 98\% identity), and Xanthomonas axonopodis pv. citri (NP641850, 98\% similarity, $97 \%$ identity).
ORF2 (a partial sequence of $102 \mathrm{bp}$ ) is immediately upstream of the fur gene and exhibited 97, 96, and 94\% nucleotide sequence identity to $\operatorname{smpA}$ (small protein $\mathrm{A}$ ) genes of $X$. axonopodis pv. citri (AE011783), X. campestris pv. phaseoli (AF146829), and X. campestris pv. campestris (AEO12247), respectively. ORF3 (a partial sequence of $192 \mathrm{bp}$ ) is immediately downstream to the fur gene, and has a transcriptional orientation in the opposite direction. ORF3 exhibited 94 and 92\% nucleotide sequence identity to recN (putative DNA repair protein) genes of X. axonopodis pv. citri (AE011783) and X. campestris pv. campestris (AE012247), respectively. The gene organization of the fur region of $X$. oryzae pv. oryzae (Fig. 1) is conserved in $X$. campestris pv. campestris and $X$. axonopodis pv. citri, except for the presence of an ORF encoding a conserved hypothetical protein of 104 amino acids between fur and recN genes in $X$. axonopodis pv. citri (da Silva et al 2002). A 440-bp intergenic region lies between the fur and recN genes in $X$. oryzae pv. oryzae. The 440-bp region was analyzed using the ORF Finder program as well as FramePlot (Ishikawa and Hotta 1999), and no ORF with significant homology or length was detected. The intergenic region also exhibited no significant similarity against the corresponding regions of $X$. campestris pv. campestris and $X$. axonopodis pv. citri when analyzed by Blast 2 (Tatusova and Madden 1999).

\section{Generation of a $X$. oryzae pv. oryzae fur mutant.}

An internal 268-bp fragment of the fur gene was cloned into pMOS and used to generate a fur mutant (strain BXO1801) of $X$. oryzae pv. oryzae (strain $\mathrm{BXO} 43$ ) by homologous recombination (Fig. 1). A fur ${ }^{+}$revertant (designated as BXO1802) was obtained by growing the fur mutant in peptone-sucrose (PS) medium without ampicillin and screening for ampicillin-sensitive $\left(\mathrm{Ap}^{\mathrm{s}}\right)$ colonies that were expected to have arisen by excision of the integrated construct. Revertants were distinguished by sensitivity to ampicillin and a bigger colony size. PCR was performed with the flanking primers (FurF and FurR1) (Fig. 1, primers 3 and 4) to obtain a product of approximately $408 \mathrm{bp}$ in the revertant as in the wild-type strain.

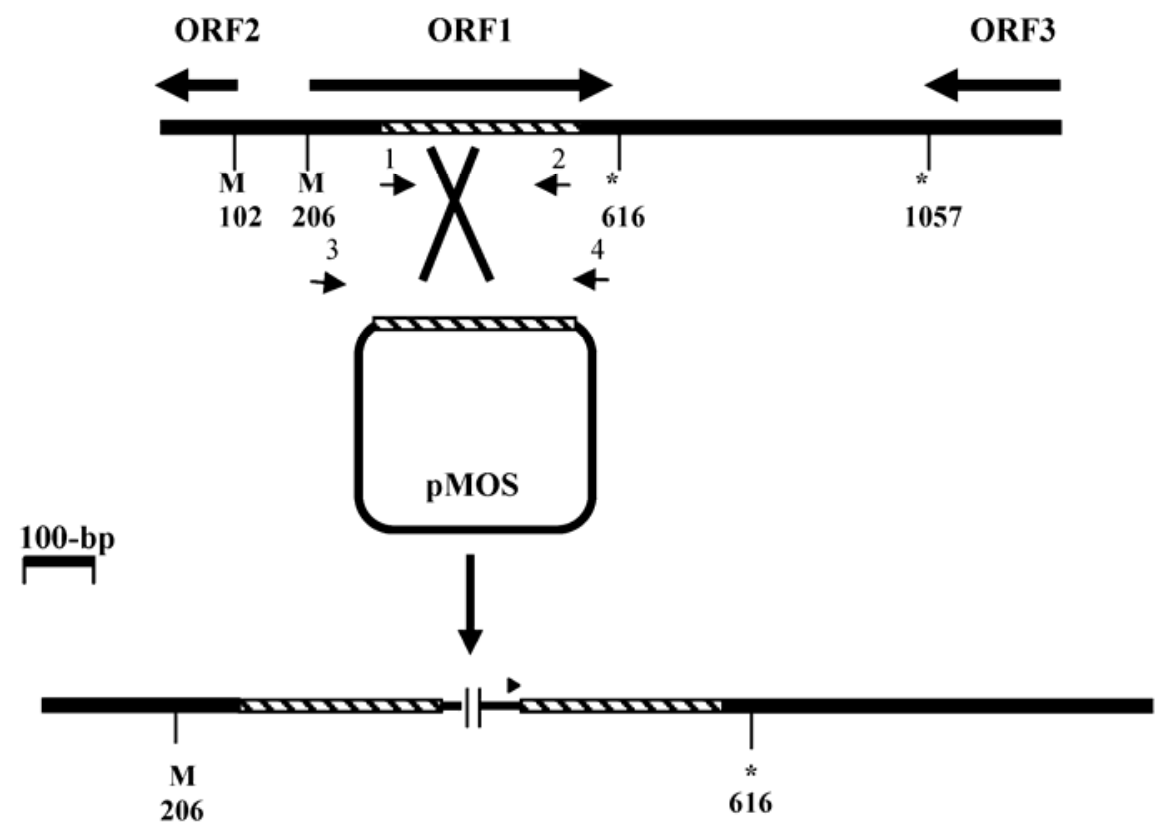

Fig. 1. Schematic of the arrangement of open reading frames (ORFs) in a 1.248-kb genomic region that encodes the Xanthomonas oryzae pv. oryzae fur gene. $\mathrm{M}$ and * represent the start and stop codons of ORFs. Large arrows represent the direction of transcription. Only partial sequences of ORFs 2 and 3 are available. The striped region indicates the internal fragment of ORF1 (fur) which was cloned in pMOS vector. Small arrows indicate the positions of different primers: Primers 1 and 2 were used to amplify the internal fragment of ORF1; primers 3 and 4 flank this region and were used to confirm mutation in ORF1. Arrowhead indicates the orientation of the lac $\mathrm{Z}$ promoter of the vector. 


\section{$X$. oryzae pv. oryzae fur mutant produces siderophores} in an unregulated manner and is hypersensitive to streptonigrin.

The chemical assay for siderophore production using chrome azurol sulphonate (CAS) was employed (Schwyn and Neilands 1987). BXO43 does not produce siderophores on peptone sucrose agar + CAS (PSA-CAS) plates (Fig. 2). However, under conditions of iron depletion caused by addition of $100 \mu \mathrm{M}$ dipyridyl (a ferrous chelator), BXO43 produces siderophores (seen as a yellowish orange halo surrounding the colonies). The fur mutant, BXO1801, produced siderophores

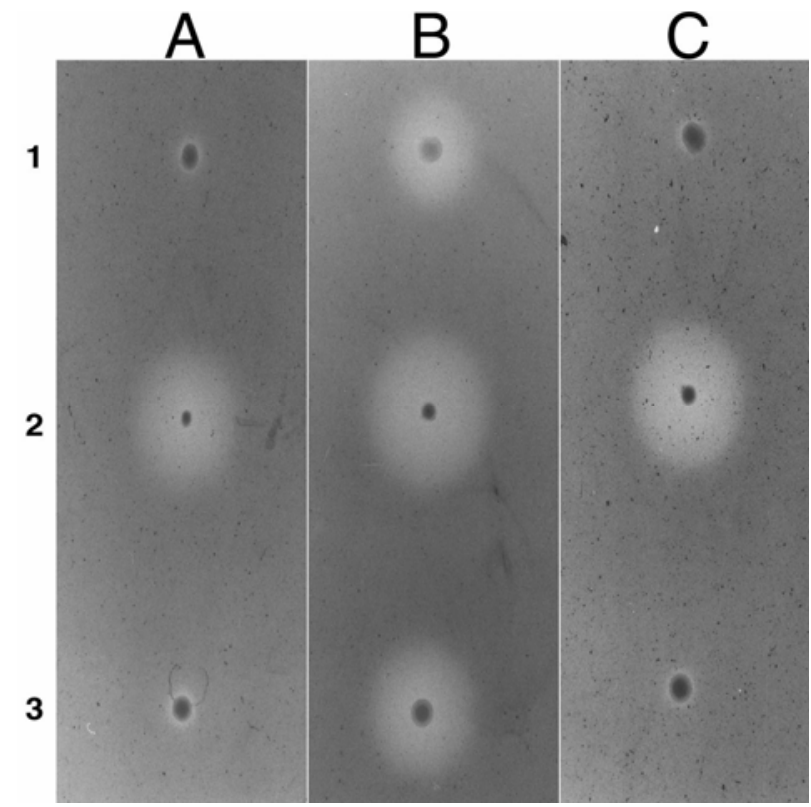

Fig. 2. Xanthomonas oryzae pv. oryzae fur mutant produces siderophores in an unregulated manner. The universal chrome azurol-S (CAS) assay for detection of secreted siderophores was performed by growing $X$. oryzae pv. oryzae strains for $36 \mathrm{~h}$ on A, peptone sucrose agar (PSA)-CAS, B, PSA-CAS + $100 \mu \mathrm{M}$ 2,2'-dipyridyl, and C, PSA-CAS + $100 \mu \mathrm{M} \mathrm{FeSO}{ }_{4}$. The halo is indicative of siderophore production. 1-BXO43 = wild type, 2 $\mathrm{BXO1801}=$ furl::bla, and 3-BXO1802 $=$ fur $^{+}$derivative of BXO1801. The fur mutant produces siderophores under all growth conditions. The wild-type and fur $^{+}$revertant strains produce siderophores only under conditions of iron starvation.

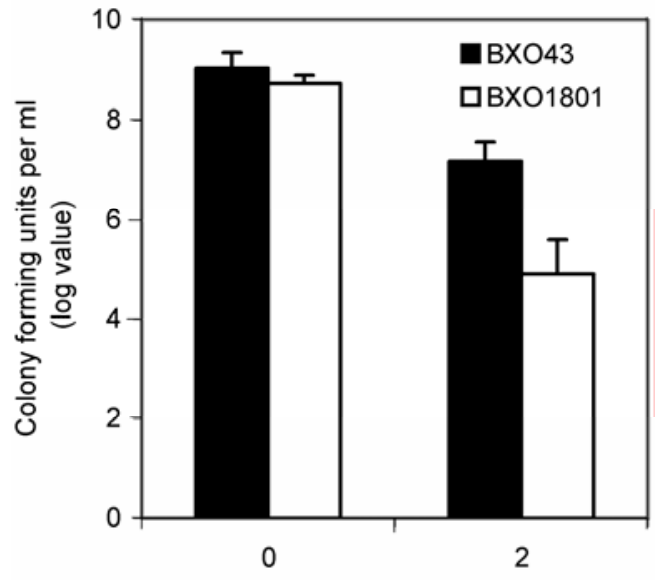

Duration of exposure to streptonigrin (h)

Fig. 3. Xanthomonas oryzae pv. oryzae fur mutant exhibits hypersensitivity to streptonigrin. $X$. oryzae pv. oryzae strains were treated with streptonigrin at $15 \mu \mathrm{g} \mathrm{ml}^{-1}$ for $2 \mathrm{~h}$ and the viable cell number was estimated by plating bacterial culture before and after treatment. BXO43 = wild-type strain and BXO1801 = furl::bla. even on PSA-CAS plates. Addition of increasing concentrations of iron in the form of ferrous sulfate (up to $100 \mu \mathrm{M}$ ) failed to abrogate siderophore production by BXO1801.

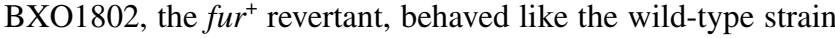
in the above assays.

The overproduction of siderophores by BXO1801 indicated the possibility that excess free iron might be present within these cells. Relative intracellular iron was assayed by the streptonigrin sensitivity assay. Streptonigrin is an antibiotic exhibiting iron-dependent catalytic activity resulting in cell death (Ming 2003). BXO1801, when given a 2-h exposure to streptonigrin $\left(15 \mu \mathrm{g} \mathrm{ml}^{-1}\right)$, showed an approximately 10 - to 100 -fold reduction in viability compared with BXO43 (Fig. 3).

\section{BXO1801 is hypersensitive to hydrogen peroxide and exhibits reduced catalase activity.}

Another feature of defects in iron regulation is concomitant changes in sensitivity to reactive oxygen species (ROS). To assess possible changes in the fur mutant, the viability of BXO43, BXO1801 (fur mutant), and BXO1802 (fur ${ }^{+}$revertant) were measured after treatment with $10 \mathrm{mM}$ hydrogen peroxide for $1 \mathrm{~h}$ (discussed below). BXO43 and BXO1802 exhibited a 10-fold reduction in cell number, whereas BXO1801 showed an almost 1,000-fold reduction in viability

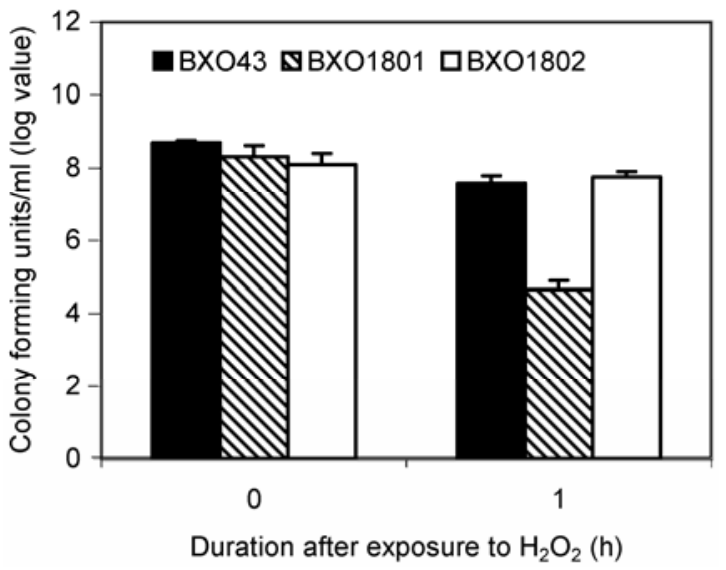

Fig. 4. Xanthomonas oryzae pv. oryzae fur mutant is hypersensitive to hydrogen peroxide. X. oryzae pv. oryzae strains were treated with $10 \mathrm{mM}$ hydrogen peroxide for $1 \mathrm{~h}$ and the viable cell number was estimated by plating bacterial cultures before and after treatment. BXO43 = wild-type strain, BXO1801 = fur1::bla, and BXO1802 = fur ${ }^{+}$derivative of BXO1801.

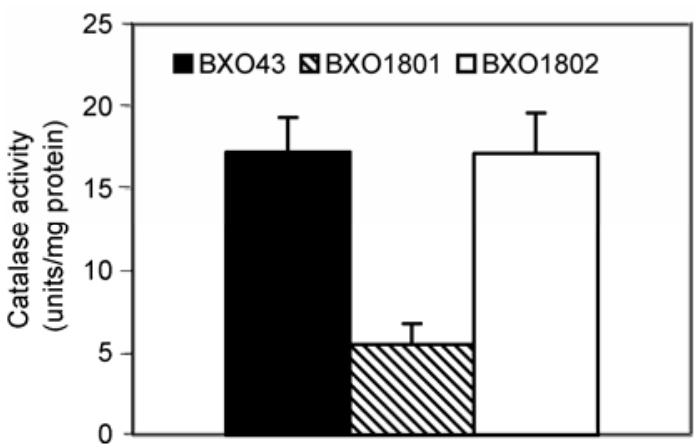

Fig. 5. Xanthomonas oryzae pv. oryzae fur mutant exhibits reduced catalase activity. The $X$. oryzae pv. oryzae wild-type (BXO43), fur mutant (BXO1801), and fur ${ }^{+}$revertant (BXO1802) were grown in PS at $28^{\circ} \mathrm{C}$ and cell extracts prepared at early log phase. Catalase activity was measured by the method of Beers and Sizer (1952). The specific activity of catalase is expressed in terms of units (micromoles of $\mathrm{H}_{2} \mathrm{O}_{2}$ decomposed per minute at $\mathrm{pH}$ 7.0) per milligram of total protein. 
after $\mathrm{H}_{2} \mathrm{O}_{2}$ treatment (Fig. 4). Catalase activity was measured in order to determine whether hypersensitivity to $\mathrm{H}_{2} \mathrm{O}_{2}$ was associated with impaired antioxidant functions. Early $\log$ phase cultures were used because $X$. oryzae pv. oryzae cultures have maximum catalase activity at this phase of growth (Chamnongpol et al. 1995). Cell extracts were prepared from BXO43, BXO1801, and BXO1802 at early log phase and activity was determined by spectrophotometry. Catalase activity of $\mathrm{BXO} 43$ and $\mathrm{BXO} 1802$ was found to be approximately 18

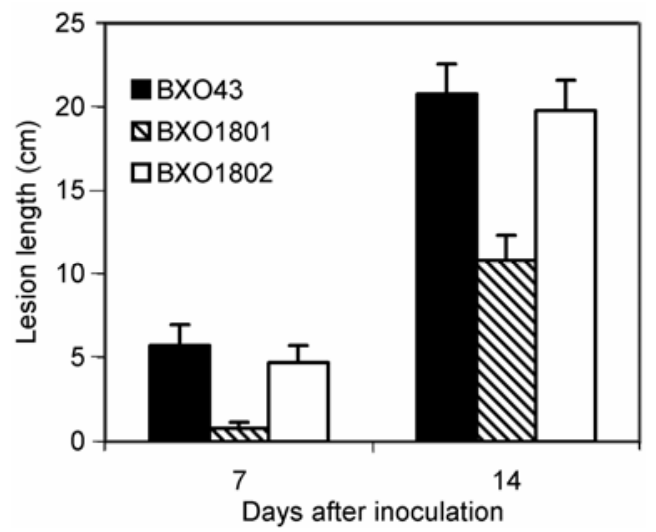

Fig. 6. Xanthomonas oryzae pv. oryzae fur mutant is virulence deficient. Virulence assays were done by wound inoculation of leaves of the susceptible rice cv. Taichung Native-1 (TN-1). Lesion lengths were measured 7 and 14 days after inoculation. Mean and standard deviation of 15 replicate measurements of lesion lengths are given. $\mathrm{BXO} 43$ = wild-type strain, $\mathrm{BXO} 1801=$ furl $::$ bla , and $\mathrm{BXO1802}=$ fur $^{+}$derivative of $\mathrm{BXO} 1801$. Similar results were obtained in independent experiments. units/mg of protein, which was approximately threefold more than BXO1801 (5.5 units/mg of protein) (Fig. 5).

\section{BXO1801 is virulence deficient}

and also exhibits a slow growth phenotype on PS medium.

Virulence was assessed by measuring lesion lengths caused on rice leaves. Compared with $\mathrm{BXO} 43$ and $\mathrm{BXO} 1802$ (fur ${ }^{+}$revertant), the lesion lengths on rice leaves caused by the BXO1801 (fur mutant) strain were reduced significantly (approximately $15 \%$ of $\mathrm{fur}^{+}$) 7 days after inoculation (DAI) (Fig. $6)$. Interestingly, lesions were found to be approximately $50 \%$ of the fur $^{+}$strains at 14 DAI. BXO1801 reverted to fur $^{+}$at a frequency of $1: 10^{4}$ fur $^{+}$:fur cells (data not shown). To determine whether the increase in lesion length was caused by a selection for $\mathrm{fur}^{+}$revertants in planta, bacteria were isolated from leaves inoculated with BXO1801. At 7 DAI, the frequency was $1: 10^{2}$ to $10^{3}$ fur $^{+}$:fur cells; whereas, at $14 \mathrm{DAI}$, it changed to $1: 1$ to 10 fur $^{+}$:fur cells. This drastic increase in the number of revertants indicated an in planta growth advantage for the $f u r^{+}$ revertants and illustrated the importance of the fur gene for pathogenicity and survival in rice leaves.

Growth curves were measured for BXO43 and BXO1801 in PS medium. BXO1801 exhibited a severe growth deficiency compared with BXO43 (Fig. 7). The relative proportion of fur $^{+}$ revertants to fur ${ }^{-}$cells was estimated, and a strong selection for fur $^{+}$revertants was observed. The ratio of fur $r^{+}$fur ${ }^{-}$was $1 \times 10^{-2}$ cells at the time of inoculation and approximately $1 \times 10^{4}$ after $48 \mathrm{~h}$ in PS medium. Between 36 and $48 \mathrm{~h}$ after inoculation, a nearly 100-fold reduction in the total number of fur ${ }^{-}$cells in the BXO1801 culture was observed. The BXO1802 strain (fur ${ }^{+}$ revertant) behaved similarly to BXO43 in these assays (data not shown).

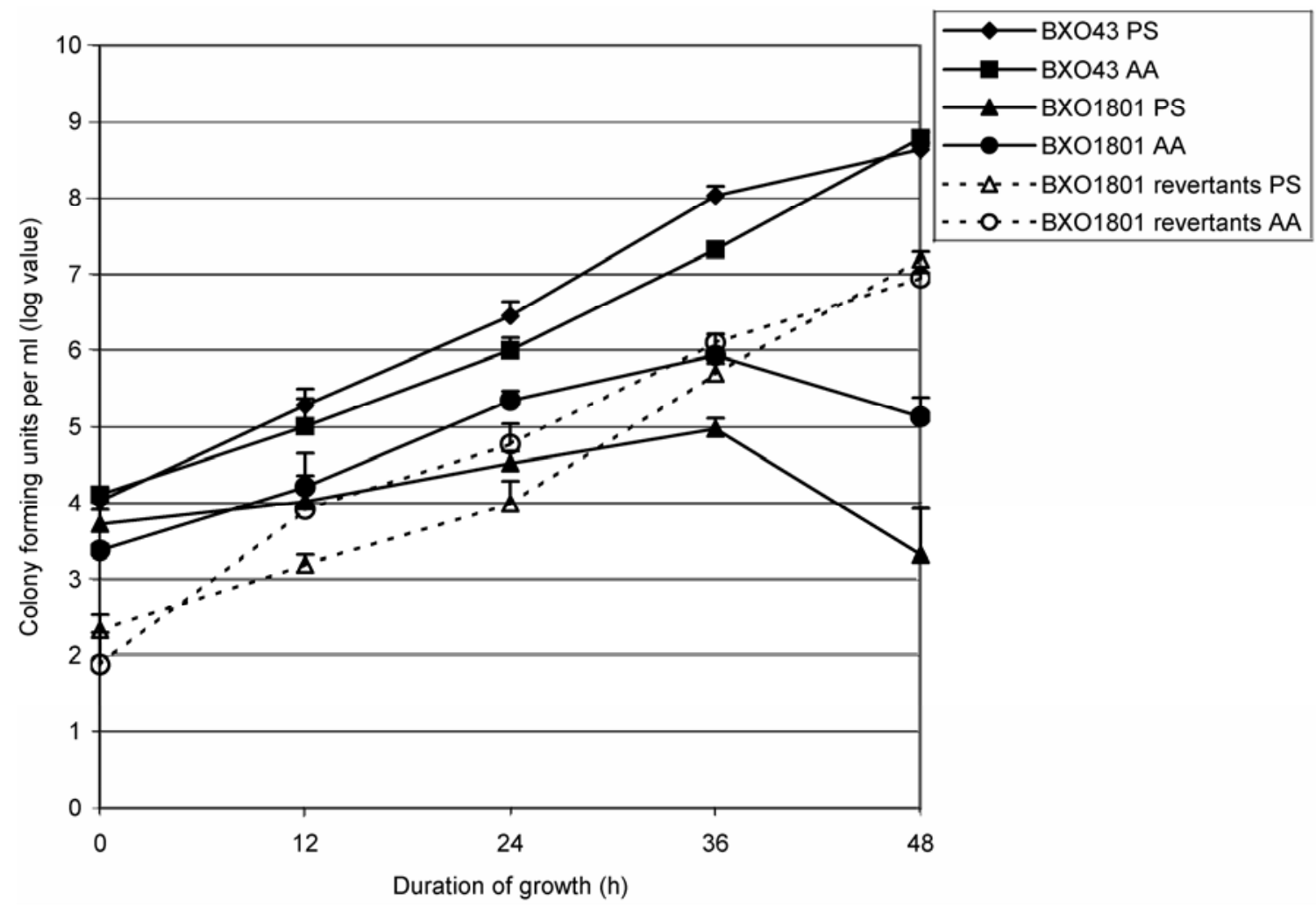

Fig. 7. Xanthomonas oryzae pv. oryzae fur mutant exhibits a slow growth phenotype in peptone-sucrose (PS) medium which is partially rescued by ascorbic acid supplementation. $X$. oryzae pv. oryzae strains were grown in PS at $28^{\circ} \mathrm{C}$ with or without ascorbic acid $(500 \mu \mathrm{M})$ and cell numbers were estimated by plating bacterial cultures at intervals. BXO43 PS and BXO43 AA = wild type without or with ascorbic acid, respectively; BXO1801 PS and BXO1801 AA = furl::bla mutant without or with ascorbic acid, respectively; and BXO1801 revertants PS and BXO1801 revertants AA $=f u r^{+}$revertants obtained in the BXO1801 culture without or with ascorbic acid, respectively. 
In planta growth defect of the $X$. oryzae pv. oryzae fur mutant is rescued by ascorbic acid supplementation.

Detached leaf inoculation experiments were carried out to determine whether the in planta growth defect of BXO1801 could be alleviated by supplementation with ascorbic acid, an antioxidant. Survival of bacteria in rice leaves was monitored by determining the viable cell number of the re-isolated bacteria (Fig. 8). The cell numbers of wild-type and fur mutant were similar (approximately $10^{3}$ - to $10^{4} \mathrm{CFU} \mathrm{ml}^{-1}$ ) without or with $500 \mu \mathrm{M}$ ascorbic acid supplementation, $1 \mathrm{~h}$ after inoculation, indicating equal efficiency in leaf entry. After $48 \mathrm{~h}$, wild-type cell numbers increased by 100 - to 1,000 -fold in either glucose alone or glucose and ascorbic acid. On the other hand, cell numbers of the fur mutant either were reduced or remained constant after $48 \mathrm{~h}$ in leaves with glucose alone. The cell numbers increased to approximately $10^{6} \mathrm{CFU} \mathrm{ml}^{-1}$ (almost wildtype level) in ascorbic acid-supplemented medium. Thus, a significant increase (approximately 100-fold) was found in the cell numbers of the fur mutant upon ascorbic acid supplementation. This experiment demonstrated that, at least in the first $48 \mathrm{~h}$ of leaf infection, the growth defect of the $X$. oryzae pv. oryzae fur mutant may be corrected by providing ascorbic acid, an antioxidant.

The effect of ascorbic acid supplementation on growth of BXO43 (fur $r^{+}$and BXO1801 (fur $\left.{ }^{-}\right)$in PS medium also was assessed. Ascorbic acid had a slight inhibitory effect on growth of BXO43 (Fig. 7). Ascorbic acid improved the growth of BXO1801 because the numbers of cells of BXO1801 were higher in PS and ascorbic acid compared with PS alone (Fig. 7 ). The reduction in the number of fur mutant cells between 36 and $48 \mathrm{~h}$ was less severe in PS and ascorbic acid compared with PS alone. However, even with ascorbic acid supplementation, BXO1801 did not grow as well as the fur ${ }^{+}$strain in PS medium and ascorbic acid only partially alleviated the slow growth phenotype of BXO1801 in PS medium.

\section{DISCUSSION}

The regulation of iron uptake is critical for vital cellular functions in an aerobic environment, and this function is carried out by the Fur protein in many bacteria. In R. leguminosarum,

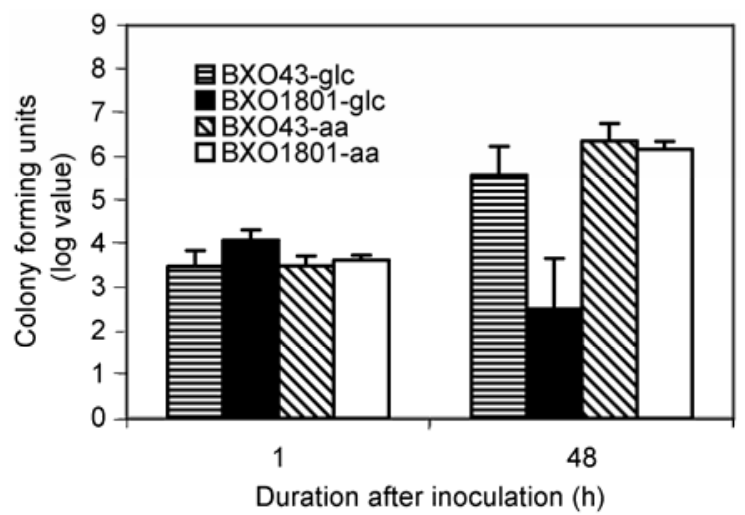

Fig. 8. In planta growth deficiency of a Xanthomonas oryzae pv. oryzae fur mutant is rescued by ascorbic acid supplementation. X. oryzae pv. oryzae strains were inoculated on leaves dipped in sterile water containing $0.1 \%$ glucose without or with ascorbic acid $(500 \mu \mathrm{M})$. Bacteria were reisolated by crushing $1 \mathrm{~cm}^{2}$ of the cut end of the leaf and viable cell numbers were estimated after 1 and $48 \mathrm{~h}$. Mean \pm standard deviation of cell numbers obtained from three different leaves are indicated for each strain. BXO43-glc and BXO43-aa = wild type without or with ascorbic acid, respectively; BXO1801-glc and BXO1801-aa = furl::bla without or with ascorbic acid, respectively. Similar results were obtained in independent experiments. many of the iron-regulated genes do not exhibit Fur-dependent expression and have been shown to be regulated by another protein, RirA (Todd et al. 2002; Wexler et al. 2003). Therefore, iron-dependent expression need not be regulated by Fur in all bacteria. The fur mutant of $X$. oryzae pv. oryzae exhibits deregulated siderophore production, a slow growth phenotype on rich medium, sensitivity to oxidative stress, and virulence deficiency. The constitutive secretion of siderophores by the fur mutant of $X$. oryzae pv. oryzae is indicative of deregulated iron uptake machinery. The identity of the genes that are involved in iron uptake or in the synthesis of siderophore in $X$. oryzae pv. oryzae is not known and additional evidence for fur-regulated iron uptake may be obtained only after identification of these genes.

Previous reports have indicated a failure to construct null mutations in the fur gene of Pseudomonas aeruginosa, Haemophilus ducreyi, and Neisseria gonorrhoea (Carson et al. 1996; Prince et al. 1993; Thomas and Sparling 1996). Although an $X$. oryzae pv. oryzae fur mutant was obtained, it grew poorly and reverted back to wild type in the absence of antibiotic selection in rich medium, indicating that a functional fur gene provides selective advantages. Complementation of the fur mutant with a cosmid containing the fur gene and the flanking genomic region resulted only in partial restoration of the wild-type phenotype for both siderophore production and growth (data not shown). Introduction of the cosmid clone improved growth of the fur mutant on PSA medium (as judged by colony size) and resulted in lesser production of siderophore (as judged by halo size on PSA-CAS plates). However, this strain did not grow as well and also produced more siderophore than the wild-type strain. The N- and C-terminal portions of the Fur protein are reported to have DNA binding and dimerization activities, respectively (Stojiljkovic and Hantke 1995). The plasmid insertion in the X. oryzae pv. oryzae fur gene resulted in a truncated fur allele in which the first $370 \mathrm{bp}$ of the 411-bp fur gene were intact. This might result in the production of a truncated Fur protein that could interfere with functioning of the wild-type protein; possibly because it might possess some residual DNA binding or dimerization activity. A dominant negative fur allele of Bradyrhizobium japonicum previously has been isolated as a spontaneous manganese resistant mutant and shown to have multiple point mutations within the fur coding sequence (Benson et al. 2004). It is interesting to note that several of these mutations result in amino acid substitutions in the extreme $\mathrm{C}$-terminal region of the protein (the equivalent region is missing in the $X$. oryzae pv. oryzae fur mutant).

Similar to E. coli, the $X$. oryzae pv. oryzae fur mutant is hypersensitive to hydrogen peroxide (Touati et al. 1995) which may be due to reduced catalase activity. In $P$. aeruginosa, fur mutants exhibit reduced catalase activity (Hassett et al. 1996). The presence of excess free intracellular iron due to deregulation of iron uptake leads to increased generation of toxic hydroxyl radicals (Touati 2000). Therefore, the excess oxidative stress, along with reduced catalase activity, might contribute to $\mathrm{H}_{2} \mathrm{O}_{2}$ hypersensitivity. The mechanism by which Fur protein affects catalase expression in $X$. oryzae pv. oryzae is not known (Masse and Gottesman 2002; Wilderman et al. 2004).

What might be the reason for reduced pathogenicity of the $X$. oryzae pv. oryzae fur mutant? Recent reports suggest that ROS are produced in compatible interactions (Venisse et al. 2003). Successful neutralization of this oxidative stress would be critical for in planta survival. Therefore, a fur mutant that is compromised in antioxidant functions would be at a tremendous disadvantage, once the plant defense reactions are induced. The removal of ROS should promote survival of the fur mutant in planta. Ascorbic acid is known to scavenge hydroxyl radicals, 
thus acting as an antioxidant (Bielski 1982; Horemans et al. 2000). The in planta growth defect of the $X$. oryzae pv. oryzae fur mutant can be rescued by supplementing with ascorbic acid. This observation suggests that the reduced virulence of the $X$. oryzae pv. oryzae fur mutant may be due, at least in part, to an inability to survive oxidative stress during infection.

Ascorbic acid supplementation does not fully alleviate the slow growth phenotype of BXO1801 in PS medium. It is possible that ascorbic acid is not taken up very efficiently by cells of $X$. oryzae pv. oryzae. In such a situation, ascorbic acid supplementation might provide better protection to the fur mutant against oxidative stress emanating from an external source (as would be experienced during growth in the leaf) compared with oxidative stress from within the cell (as would be experienced during growth in PS medium). Alternatively, enhanced oxidative stress may be only partially responsible for the slow growth phenotype of the fur mutant in PS medium. More studies on the fur regulon of $X$. oryzae pv. oryzae are needed to understand how Fur controls iron uptake, response to oxidative stress, and growth in laboratory conditions and within the plant.

\section{MATERIALS AND METHODS}

\section{Bacterial strains, plasmids, and culture media.}

The $X$. oryzae pv. oryzae strains used were BXO43 (rif-2, rifampicin resistant; laboratory wild-type strain), BXO1801

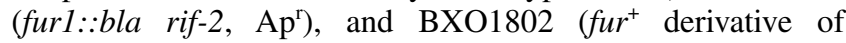
$\left.\mathrm{BXO1801,} \mathrm{Ap}^{\mathrm{s}}\right)$. These strains were grown at $28^{\circ} \mathrm{C}$ in PS medium (Tsuchiya et al. 1982). pSS1 (pMOS Blue + 268-bp PCR product amplified from fur), was generated and maintained in Escherichia coli strain DH10B (Invitrogen Life Technologies, Carlsbad, CA, U.S.A.). E. coli cells were cultured at $37^{\circ} \mathrm{C}$ in Luria Bertani medium (Miller 1992). The concentrations of antibiotics used were rifampicin (Rf) at $50 \mu \mathrm{g} \mathrm{m}^{-1}$, ampicillin (Ap) at $100 \mu \mathrm{g} \mathrm{ml}^{-1}$, cylcloheximide (Cy) at $80 \mu \mathrm{g} \mathrm{ml}^{-1}$, and

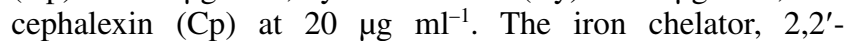
dipyridyl, was used at a concentration of $100 \mu \mathrm{M}$ from a 10 $\mathrm{mM}$ stock solution made in sterile water. Streptonigrin was made in sterile water as a stock solution at $1 \mathrm{mg} \mathrm{ml}^{-1}$ and the concentration used was $15 \mu \mathrm{g} \mathrm{ml}^{-1}$.

\section{Generation of a fur mutant of $X$. oryzae pv. oryzae.}

An internal fragment of the $X$. oryzae pv. oryzae fur gene was amplified using primers FurF1 (5'-GCAGAAGACATCTATCGCCAG-3') and FurR (5'-GCTCTTCGAGTTCATAGC CG-3'). The fragment was cloned into the PCR cloning vector pMOS (Amersham Pharmacia Biotech, Uppsala, Sweden) to obtain the pSS1 plasmid, which was sequenced to verify the identity of the cloned product. Approximately $500 \mathrm{ng}$ of the plasmid was introduced by electroporation into electrocompetent cells of BXO43 (wild-type strain). The transformants were grown in PS for $3 \mathrm{~h}$ and then plated on PSA containing Ap. Integration of the plasmid into the genome of $\mathrm{Ap}^{\mathrm{r}}$ colonies was confirmed by PCR using flanking primers FurF (5'-ATGGAA ACCCACGACCTGC-3') and FurR1 (5'-GCGCGGACGCTTC TTGC-3') in combination with vector-specific primers M13F and T7. Sequencing of the PCR products was done to confirm integration into the fur gene.

\section{Plasmid isolation and other molecular techniques.}

Plasmid isolation was by the alkaline lysis method as described (Sambrook et al. 1989). Restriction digestions were done, as required, with enzymes obtained from NEB (New England Biolabs, Beverly, MA, U.S.A.) as per the supplier's instructions. Inverse PCR to obtain the DNA sequences flanking the $X$. oryzae pv. oryzae fur gene was done by digesting 2 $\mu \mathrm{g}$ of wild-type genomic DNA with enzymes Sau96I and BfaI. After cleaning of the digested DNA, $50 \mathrm{ng}$ was taken for overnight ligation in a 50- $\mu$ l volume to circularize the DNA fragments. Different aliquots of the ligated product were taken for inverse PCR using the FR1 primer (5'-CGCTGCAGCGCCAGATTGCC-3') to obtain sequence downstream of fur and the FR2 primer (5'-CTCTTTTGCTCCAGCAATTCC-3') to obtain upstream sequence. Sequencing of the PCR products was performed with an ABI Prism 3700 automated DNA sequencer (Perkin-Elmer, Foster City, CA, U.S.A.). Similarity searches were performed in the NCBI database, using the BLAST algorithm (Altschul et al. 1990). ORF searches were done using ORF Finder of the National Center for Biotechnology Information and FramePot 2.3.2 (Ishikawa and Hotta 1999).

\section{Siderophore production assay.}

CAS containing siderophore indicator plates was prepared as described by Schwyn and Neilands (1987). X. oryzae pv. oryzae grows very poorly on minimal medium; therefore, the siderophore indicator plates were made in PS instead of MM9 medium. $X$. oryzae pv. oryzae strains were patched on PSACAS plates and incubated at $28^{\circ} \mathrm{C}$. In order to create iron depleted conditions, 2,2'-dipyridyl $(100 \mu \mathrm{M})$ was added to PSACAS plates. Similarly, PSA-CAS plates were supplemented with ferrous sulfate $(100 \mu \mathrm{M})$ when required. The colonies were scored for the orange halo phenotype after $36 \mathrm{~h}$.

\section{Sensitivity to hydrogen peroxide and streptonigrin.}

$X$. oryzae pv. oryzae strains were grown in $3 \mathrm{ml}$ of PS to a cell density of $10^{8} \mathrm{CFU} \mathrm{ml} \mathrm{m}^{-1}$. Bacterial cultures were dilution plated on PSA to obtain cell numbers before treatment with either $\mathrm{H}_{2} \mathrm{O}_{2}$ (Loba Chemie, Mumbai, India) or streptonigrin. $\mathrm{H}_{2} \mathrm{O}_{2}$ was added to the culture at a concentration of $10 \mathrm{mM}$ and incubated at $28^{\circ} \mathrm{C}$ and $150 \mathrm{rpm}$ for $1 \mathrm{~h}$. Streptonigrin was added to the culture at a concentration of $15 \mu \mathrm{g} \mathrm{ml} \mathrm{m}^{-1}$ and incubated at $28^{\circ} \mathrm{C}$ and $150 \mathrm{rpm}$ for $2 \mathrm{~h}$. The cells then were pelleted and washed once with sterile distilled water before plating to count cell number. The logarithmic value of viable cells per milliliter of culture is indicated as mean \pm standard deviation (SD).

\section{Preparation of cell extracts and catalase assay.}

Bacterial cultures were grown initially for $30 \mathrm{~h}$ in PS (for the fur mutant, ampicillin was added to prevent revertant accumulation) to obtain pre-inoculum. The fur mutant had to be grown for a longer period ( $48 \mathrm{~h})$ to obtain pre-inoculum with the same cell number as the wild type. Into $30 \mathrm{ml}$ of PS in a $100-\mathrm{ml}$ flask, $5 \%$ pre-inoculum was added and grown at $28^{\circ} \mathrm{C}$, $150 \mathrm{rpm}$ (Chamnongpol et al. 1995). Cells were pelleted at early $\log$ phase (after $2 \mathrm{~h}$ of growth) by centrifugation at 7,000 rpm for $10 \mathrm{~min}$. Cell pellets were suspended in $50 \mathrm{mM}$ potassium phosphate buffer containing $0.1 \mathrm{mM}$ EDTA. The cell suspension was disrupted by sonication with 0.5 -s pulses for 2 min, with a 1-min interval during which the probe was removed from the sample. Tubes containing the samples were always kept on ice. Debris was pelleted by centrifugation at 13,000 rpm for $10 \mathrm{~min}$. Total protein concentration was measured by the method of Bradford (1976), with bovine serum albumin as the standard. Catalase was assayed by the method of Beers and Sizer (1951). Briefly, 5 to $25 \mu \mathrm{l}$ of total protein extract was diluted to $1 \mathrm{ml}$ with double-distilled water (DDW). A 59-mM $\mathrm{H}_{2} \mathrm{O}_{2}$ solution was prepared from a $10-\mathrm{M}$ stock solution by freshly diluting in $50 \mathrm{mM}$ potassium phosphate buffer, $\mathrm{pH}$ 7.0. To $1 \mathrm{ml}$ of the sample in a cuvette, $0.5 \mathrm{ml}$ of $59-\mathrm{mM} \mathrm{H}_{2} \mathrm{O}_{2}$ was added and the absorbance at $240 \mathrm{~nm}$ was measured every $10 \mathrm{~s}$ for $1 \mathrm{~min}$, to calculate the decrease in absorbance in that time period (expressed as $\Delta A_{240} \mathrm{~min}^{-1}$ ). The specific activity of cata- 
lase was calculated as follows: $1,000 \times \Delta A_{240} \mathrm{~min}^{-1} / 43.6 \times$ milligram of protein $\mathrm{ml}^{-1}$ of reaction mixture (Visick and Clarke 1997).

\section{Virulence assays on rice plants.}

Virulence assays were performed on approximately 40-dayold rice plants of the highly susceptible rice cv. Taichung Native (TN-1) in the greenhouse. Inoculation was done by clipping leaf tips with scissors dipped in bacterial culture $\left(10^{8} \mathrm{CFU} / \mathrm{ml}\right.$ resuspended in sterile DDW) (Kauffman et al. 1973). BXO1801 was grown in PS $+\mathrm{Ap}+2,2^{\prime}$-dipyridyl to minimize the number of revertants in the culture at the time of inoculation. To maintain similar growth conditions, BXO43 and BXO1802 also were grown in PS $+2,2^{\prime}$-dipyridyl. Inoculated plants were incubated in the greenhouse and lesion lengths were taken 7 and 14 DAI. Control inoculations were performed with scissors dipped in sterile water and no lesions were observed. In each experiment, 15 leaves were inoculated and the lesion length was calculated as the mean of all individual lesion lengths \pm SD. Similar results were obtained in independent experiments.

\section{Re-isolation of bacteria \\ from rice leaves and fur $^{+}$revertant identification.}

Infected leaves were surface sterilized by dipping in $1 \%$ (vol/vol) sodium hypochlorite (Loba Chemie) for $1 \mathrm{~min}$ and washing three times in distilled water. The leaves were cut at the leading edge of the lesion and dipped in $1 \mathrm{ml}$ of sterile water for $5 \mathrm{~min}$. Bacteria that exuded from the cut edge of the leaf were isolated by plating for individual colonies on PSA. The fur $^{+}$revertants were identified by their larger colony size, and these colonies then were patched on PSA-CAS plates for halo phenotype (no halo was detected because these colonies would behave like the wild type) and on PSA + Ap plates to detect loss of the previously integrated construct (such colonies were sensitive to ampicillin). Colonies of smaller size also were examined and, as expected, found to have characteristics of the fur mutant strain.

\section{Detached leaf inoculation experiment with exogenous ascorbic acid supplementation.}

Leaves of 40-day-old greenhouse-grown rice plants of the susceptible rice cv. TN-1 were cut with scissors $2 \mathrm{~cm}$ above the junction of the leaf blade and sheath, and were dipped in 250-ml conical flasks (20 leaves per flask) containing $100 \mathrm{ml}$ of $0.1 \%$ glucose in DDW, as described previously (Chatterjee and Sonti 2002), with or without $500 \mu \mathrm{M}$ ascorbic acid (Sigma-Aldrich, St. Louis). The leaves were maintained for 24 $\mathrm{h}$ on a laboratory bench top prior to inoculation with different strains of $X$. oryzae pv. oryzae by leaf-clip method (Kauffman et al. 1973). At desired time intervals, the infected leaves were surface sterilized as mentioned above. Leaf material $\left(1 \mathrm{~cm}^{2}\right)$ from the point of inoculation was taken, crushed using a mortar and pestle in $1 \mathrm{ml}$ of sterile DDW, and dilution plated on PSA media containing $\mathrm{Rf}+\mathrm{Cp}+\mathrm{Cy}$. After 3 to 4 days, colonies were counted and mean \pm SD of the logarithmic value of cell number obtained from three different leaves was calculated. Similar results were obtained in independent experiments.

\section{Growth experiments.}

Bacterial cultures were grown initially in PS to obtain preinoculum and $0.1 \%$ pre-inoculum of wild-type and mutant cells was added in PS, with or without $500 \mu \mathrm{M}$ ascorbic acid, and grown at $28^{\circ} \mathrm{C}$ and $200 \mathrm{rpm}$. To determine the cell numbers per milliliter of culture, appropriate dilutions were plated on PSA plates at regular intervals. For the BXO1801 strain, in addition to PSA medium (to determine the total cell number in the culture), plating also was done on Ap-containing medium (to determine the total number of fur- $1::$ bla mutant cells in the culture). After 4 days, colonies were counted and expressed as mean \pm SD of logarithmic value of cell number per milliliter at different intervals. An estimation of number of fur $^{+}$revertants in the BXO1801 culture was obtained by subtracting the cell numbers obtained on Ap-containing medium from that on PSA medium. A representative number of the $\mathrm{Ap}^{\mathrm{r}}$ and $\mathrm{Ap}^{\mathrm{s}}$ cells were checked for the siderophore overproduction phenotype. As expected, the $\mathrm{Ap}^{\mathrm{r}}$ colonies exhibited excess siderophore secretion whereas the $\mathrm{Ap}^{\mathrm{s}}$ colonies were similar to the wild-type strain.

\section{ACKNOWLEDGMENTS}

S. Subramoni was supported by a fellowship from the Council of Scientific and Industrial Research (CSIR), Government of India. We thank M. Sultana for primer synthesis and N. Nagesh for DNA sequencing.

\section{LITERATURE CITED}

Altschul, S. F., Gish, W., Miller, W., Myers, E. W., and Lipman, D. J. 1990. Basic local alignment search tool. J. Mol. Biol. 215:403-410.

Bai, J., Choi, S. H., Ponciano, G., Leung, H., and Leach, J. E. 2000. Xanthomonas oryzae pv. oryzae avirulence genes contribute differently and specifically to pathogen aggressiveness. Mol. Plant-Microbe Interact. 13:1322-1329.

Barton, H. A., Johnson, Z., Cox, C. D., Vasil, A. I., and Vasil, M. L. 1996 Ferric uptake regulator mutants of Pseudomonas aeruginosa with distinct alterations in the iron-dependent repression of exotoxin A and siderophores in aerobic and microaerobic environments. Mol. Microbiol. 21:1001-1017.

Beers, R. F., Jr., and Sizer, I. W. 1951. A spectrophotometric method for measuring the breakdown of hydrogen peroxide by catalase. J. Biol. Chem. 196:133-140.

Benson, H. P., LeVier, K., and Guerinot, M. L. 2004. A dominant-negative fur mutation in Bradyrhizobium japonicum. J. Bacteriol. 186:14091414

Bielski, B. H. J. 1982. Page 81 in: Ascorbic Acid: Chemistry, Metabolism and Uses. P. A. Seib and B. M. Tolbert, eds. Advances in Chemistry Series 200, American Chemical Society, Washington, D.C.

Bijlsma, J. J., Waidner, B., Vliet, A H., Hughes, N. J., Hag, S., Bereswill, S., Kelly, D. J., Vandenbroucke-Grauls, C. M., Kist, M., and Kusters, J. G. 2002. The Helicobacter pylori homologue of the ferric uptake regulator is involved in acid resistance. Infect. Immun. 70:606-611.

Bradford, M. M. 1976. A rapid and sensitive method for quantification of microgram quantities of protein utilizing the principle of protein-dye binding. Anal. Biochem. 72:248-254.

Carson, S. D., Thomas, C. E., and Elkins, C. 1996. Cloning and sequencing of a Haemophilus ducreyi fur homolog. Gene 176:125-129.

Chamnongpol, S., Mongkolsuk, S., Vattanaviboon, P., and Fuangthong, M. 1995. Unusual growth phase and oxygen tension regulation of oxidative stress protection enzymes, catalase and superoxide dismutase, in the phytopathogen Xanthomonas oryzae pv. oryzae. Appl. Environ. Microbiol. 61:393-396.

Chatterjee, S., Sankaranarayanan, R., and Sonti, R.V. 2003. PhyA, a secreted protein of Xanthomonas oryzae pv. oryzae, is required for optimum virulence and growth on phytic acid as a sole phosphate source. Mol. Plant-Microbe Interact. 16:973-982.

Chatterjee, S., and Sonti, R.V. 2002. rpfF mutants of Xanthomonas oryzae pv. oryzae are deficient for virulence and growth under low iron conditions. Mol. Plant-Microbe Interact. 15:463-471.

da Silva, A. C., Ferro, J. A., Reinach, F. C., Farah, C. S., Furlan, L. R., Quaggio, R. B., Monteiro-Vitorello, C. B., Van Sluys, M. A., Almeida, N. F., Alves, L. M., do Amaral, A. M., Bertolini, M. C., Camargo, L. E., Camarotte, G., Cannavan, F., Cardozo, J., Chambergo, F., Ciapina, L. P., Cicarelli, R. M., Coutinho, L. L., Cursino-Santos, J. R., El-Dorry, H., Faria, J. B., Ferreira, A. J., Ferreira, R. C., Ferro, M. I., Formighieri, E. F., Franco, M. C., Greggio, C. C., Gruber, A., Katsuyama, A. M., Kishi, L. T., Leite, R. P., Lemos, E. G., Lemos, M. V., Locali, E. C., Machado, M. A., Madeira, A. M., Martinez-Rossi, N. M., Martins, E. C., Meidanis, J., Menck, C. F., Miyaki, C. Y., Moon, D. H., Moreira, L. M., Novo, M. T., Okura, V. K., Oliveira, M. C., Oliveira, V. R., Pereira, H. A., Rossi, A., Sena, J. A., Silva, C., de Souza, R. F., Spinola, L. A., Takita, M. A., Tamura, R. E., Teixeira, E. C., Tezza, R. I., Trindade dos Santos, M., Truffi, D., Tsai, S. M., White, F. F., Setubal, J. C., and 
Kitajima, J. P. 2002. Comparison of the genomes of two Xanthomonas pathogens with differing host specificities. Nature 417:459-463.

Dharmapuri, S., and Sonti, R. V. 1999. A transposon insertion in the gumG homologue of Xanthomonas oryzae pv. oryzae causes loss of extracellular polysaccharide production and virulence. FEMS (Fed. Eur. Microbiol. Soc.) Lett. 179:53-59.

Franza, T., Sauvage, C., and Expert, D. 1999. Iron regulation and pathogenicity in Erwinia chrysanthemi 3937: role of the Fur repressor protein. Mol. Plant-Microbe Interact. 12:119-128.

Grifantini, R., Sebastian, S., Frigimelica, E., Draghi, M., Bartolini, E., Muzzi, A., Rappuoli, R., Grandi, G., and Genco, C. A. 2003. Identification of iron-activated and -repressed Fur-dependent genes by transcriptome analysis of Neisseria meningitidis group B. Proc. Natl. Acad. Sci. U.S.A. 100:9542-9547.

Hassett, D. J., Sokol, P. A., Howell, M. L., Ma, J. F., Schweizer, H. T., Ochsner, U., and Vasil, M. L. 1996. Ferric uptake regulator (Fur) mutants of Pseudomonas aeruginosa demonstrate defective siderophoremediated iron uptake, altered aerobic growth, and decreased superoxide dismutase and catalase activities. J. Bacteriol. 178:3996-4003.

Horemans, N., Foyer, C. H., and Asard, H. 2000. Transport and action of ascorbate at the plant plasma membrane. Trends Plant Sci. 5: 263-267.

Ishikawa, J., and Hotta, K. 1999. FramePlot: a new implementation of the frame analysis for predicting protein-coding regions in bacterial DNA with a high $\mathrm{G}+\mathrm{C}$ content. FEMS (Fed. Eur. Microbiol. Soc.) Microbiol. Lett. 174:251-253.

Kamdar, H. V., Kamoun, S., and Kado, C. I. 1993. Restoration of pathogenicity of avirulent Xanthomonas oryzae pv. oryzae and X. campestris pathovars by reciprocal complementation with hrpXo and $h r p X c$ genes and identification of HrpX function by sequence analyses. J. Bacteriol. 175:2017-2025.

Kauffman, H. E., Reddy, A. P. K., Hsieh, S. P. Y., and Merca, S. D. 1973. An improved technique for evaluation of resistance of rice varieties to Xanthomonas oryzae pv. oryzae. Plant Dis. Rep. 57:537-541.

Loprasert, S., Sallabhan, R., Atichartpongkul, S., and Mongkolsuk, S. 1999. Characterization of a ferric uptake regulator (fur) gene from Xanthomonas campestris pv. phaseoli with unusual primary structure, genome organization, and expression patterns. Gene 239:251-258.

Masse, E., and Gottesman, S. 2002. A small RNA regulates the expression of genes involved in iron metabolism in Escherichia coli. Proc. Natl. Acad. Sci. U.S.A. 99:4620-4625.

Mila, I., Scalbert, A., and Expert, D. 1996. Iron withholding by plant polyphenols and resistance to pathogens and rots. Phytochemistry 42:15511555.

Miller, J. H. 1992. A Short Course in Bacterial Genetics: A Laboratory Manual for Escherichia coli and Related Bacteria. Cold Spring Harbor Laboratory Press, Cold Spring Harbor, NY, U.S.A.

Ming, L. J. 2003. Structure and function of "metalloantibiotics". Med Res. Rev. 23:697-762.

Neema, C., Laulhere, J. P., and Expert, D. 1993. Iron deficiency induced by chrysobactin in saintpaulia leaves inoculated with Erwinia chrysanthemi. Plant Physiol. 102:967-973.

Payne, S. M. 1993. Iron acquisition in microbial pathogenesis. Trends Microbiol. 1:66-69.

Postle, K., and Kadner, R. J. 2003. Touch and go: tying TonB to transport. Mol. Microbiol. 49:869-882.

Prince, R. W., Cox, C. D., and Vasil, M. L. 1993. Coordinate regulation of siderophore and exotoxin A production: molecular cloning and sequencing of the Pseudomonas aeruginosa fur gene. J. Bacteriol. 175:2589-2598.

Rajeshwari, R., and Sonti, R. V. 2000. Stationary-phase variation due to transposition of novel insertion elements in Xanthomonas oryzae pv. oryzae. J. Bacteriol. 182:4797-4802.

Ratledge, C., and Dover, L. G. 2000. Iron metabolism in pathogenic bacteria. Annu. Rev. Microbiol. 54:881-941.

Ray, S. K., Rajeshwari, R., Sharma, Y., and Sonti, R. V. 2002. A high molecular-weight outer membrane protein of Xanthomonas oryzae pv. oryzae exhibits similarity to non-fimbrial adhesions of animal pathogenic bacteria and is required for optimum virulence. Mol. Microbiol. 46:637-647

Sambrook, J., Fritsch, E. F., and Maniatis, T. A. 1989. Molecular Cloning: A Laboratory Manual. Cold Spring Harbor Laboratory, Cold Spring Harbor, NY, U.S.A.

Schwyn, B., and Neilands, J. B. 1987. Universal chemical assay for the detection and determination of siderophores. Anal. Biochem. 160:47-56.
Stojiljkovic, I., and Hantke, K. 1995. Functional domains of the Escherichia coli ferric uptake regulator protein (Fur). Mol. Gen. Genet. 247: 199-205.

Tang, J.-L., Feng, J.-X., Li, Q.-Q., Wen, H.-X., Zhou, D.-L., Wilson, T. J. G., Dow, J. M., Ma, Q.-S., and Daniels, M. J. 1996. Cloning and characterization of the $r p f C$ gene of Xanthomonas oryzae pv. oryzae: Involvement in exopolysaccharide production and virulence to rice. Mol. Plant-Microbe Interact. 9:664-666.

Tatusova, T. A., and Madden, T. L. 1999. Blast 2 sequences-A new tool for comparing protein and nucleotide sequences. FEMS (Fed. Eur Microbiol. Soc.) Microbiol. Lett. 174:247-250.

Thomas, C. E., and Sparling, P. F. 1996. Isolation and analysis of a fur mutant of Neisseria gonorrhoeae. J. Bacteriol. 178:4224-4232.

Thompson, D. K., Beliaev, A. S., Giometti, C. S., Tollaksen, S. L., Khare, T., Lies, D.P., Nealson, K. H., Lim, H., Yates, J., III., Brandt, C. C., Tiedje, J. M., and Zhou, J. 2002. Transcriptional and proteomic analysis of a ferric uptake regulator (fur) mutant of Shewanella oneidensis: possible involvement of fur in energy metabolism, transcriptional regulation, and oxidative stress. Appl. Environ. Microbiol. 68:881-892.

Todd, J. D., Wexler, M., Sawers, G., Yeoman, K. H., Poole, P. S., and Johnston, A. W. 2002. RirA, an iron-responsive regulator in the symbiotic bacterium Rhizobium leguminosarum. Microbiology 148:4059-4071.

Touati, D. 2000. Iron and oxidative stress in bacteria. Arch. Biochem. Biophys. 373:1-6.

Touati, D., Jacques, M., Tardat, B., Bouchard, L., and Despied, S. 1995. Lethal oxidative damage and mutagenesis are generated by iron in delta fur mutants of Escherichia coli: protective role of superoxide dismutase. J. Bacteriol. 177:2305-2314.

Tsuchiya, K., Mew, T. W., and Wakimoto, S. 1982. Bacteriological and pathological characteristics of wild-type and induced mutants of Xanthomonas campestris pv. oryzae. Phytopathology 72:43-46.

Vasil, M. L., and Ochsner, U. A. 1999. The response of Pseudomonas aeruginosa to iron: genetics, biochemistry and virulence. Mol. Microbiol. 34:399-413.

Velayudhan, J., Hughes, N. J., McColm, A. A., Bagshaw, J., Clayton, C. L., Andrews, S. C., and Kelly, D. J. 2000. Iron acquisition and virulence in Helicobacter pylori: a major role for FeoB, a high-affinity ferrous iron transporter. Mol. Microbiol. 37:274-286.

Venisse, J. S., Barny, M. A., Paulin, J. P., and Brisset, M. N. 2003. Involvement of three pathogenicity factors of Erwinia amylovora in the oxidative stress associated with compatible interaction in pear. FEBS (Fed. Eur. Biol. Soc.) Lett. 537:198-202.

Visick, J. E., and Clarke, S. 1997. RpoS- and OxyR-independent induction of HPI catalase at stationary phase in Escherichia coli and identification of rpoS mutations in common laboratory strains. J. Bacteriol. 179:41584163

Weinberg, E. D. 1984. Iron withholding: a defense against infection and neoplasia. Physiol. Rev. 64:65-102.

Wexler, M., Todd, J. D., Kolade, O., Bellini, D., Hemmings, A. M., Sawers, G., and Johnston, A. W. 2003. Fur is not the global regulator of iron uptake genes in Rhizobium leguminosarum. Microbiology 49:1357-1365.

Wiggerich, H. G., Klauke, B., Koplin, R., Priefer, U. B., and Puhler, A 1997. Unusual structure of the tonB-exb DNA region of Xanthomonas campestris pv. campestris: tonB, exbB, and exbD1 are essential for ferric iron uptake, but $e x b D 2$ is not. J. Bacteriol. 179:7103-7110.

Wilderman, P. J., Sowa, N. A., FitzGerald, D. J., FitzGerald, P. C., Gottesman, S., Ochsner, U. A., and Vasil, M. L. 2004. Identification of tandem duplicate regulatory small RNAs in Pseudomonas aeruginosa involved in iron homeostasis. Proc. Natl. Acad. Sci. U.S.A. 101:97929797

Yang, B., Zhu, W., Johnson, L. B., and White, F. F. 2000. The virulence factor AvrXa7 of Xanthomonas oryzae pv. oryzae is a type III secretion pathway-dependent nuclear-localized double-stranded DNA-binding protein. Proc. Natl. Acad. Sci. U.S.A. 97:9807-9812.

Zhu, W., MaGbanua, M. M., and White, F. F. 2000. Identification of two novel hrp-associated genes in the hrp gene cluster of Xanthomonas oryzae pv. oryzae. J. Bacteriol. 182:1844-1853.

\section{AUTHOR-RECOMMENDED INTERNET RESOURCES}

National Centre for Biotechnology Information website: www.ncbi.nlm.nih.gov

National Institutes of Health Frame Plot 2.3.2 website: www.nih.go.jp 